University of Nebraska - Lincoln

DigitalCommons@University of Nebraska - Lincoln

Proceedings of the 6th Vertebrate Pest

Conference (1974)

Vertebrate Pest Conference Proceedings

collection

March 1974

\title{
EMERGENCY RABID SKUNK CONTROL IN MONTANA
}

Kenneth Seyler

Department of Livestock Brands-Enforcement Division, Helena, Montana

Carter Niemeyer

Brands-Enforcement Division, Helena, Montana

Follow this and additional works at: https://digitalcommons.unl.edu/vpc6

Part of the Environmental Health and Protection Commons

Seyler, Kenneth and Niemeyer, Carter, "EMERGENCY RABID SKUNK CONTROL IN MONTANA" (1974). Proceedings of the 6th Vertebrate Pest Conference (1974). 41.

https://digitalcommons.unl.edu/vpc6/41

This Article is brought to you for free and open access by the Vertebrate Pest Conference Proceedings collection at DigitalCommons@University of Nebraska - Lincoln. It has been accepted for inclusion in Proceedings of the 6th Vertebrate Pest Conference (1974) by an authorized administrator of DigitalCommons@University of Nebraska Lincoln. 


\section{EMERGENCY RABID SKUNK CONTROL IN MONTANA}

KENNETH SEYLER, Environmental Coordinator, Department of Livestock Brands-Enforcement Division, Helena, Montana

CARTER NIEMEYER, Biologist, Department of Livestock, Brands-Enforcement Division, Helena, Montana

ABSTRACT: A maximum of 500 strychnine eggs were placed in designated skunk habitat within a three mile radius where rabid skunks were diagnosed as an emergency control method to reduce or prevent the spread of rabies in striped skunk (Mephitis mephitis) populations in Northeastern Montana. The effects of strychnine on skunk and other non-target species populations were evaluated. When placed in primary skunk habitat, the toxicant eggs were selective in removing striped skunks. Scent post surveys indicated that skunk populations were reduced, while non-target species populations remained stable or increased in control areas. The effects of the toxicant egg program in reducing the incidence of rabies in striped skunks in Northeastern Montana is not clear after only one year of data. Close surveillance of the emergency skunk control areas in succeeding years may indicate the need for continuation or expansion of similar programs.

\section{INTRODUCTION}

Presently the occurrence of rabid skunks is an endemic problem of Eastern Montana. It is not known how long rabid skunks have been present in Montana. The first laboratory confirmation in the state was made in Fallon County on April 21, 1964. Since the first reported incident, a total of 82 rabid skunks have been diagnosed, with all but five cases being located in extreme Eastern Montana Counties.

Because no other species of mammals appear to be involved in the epizootic or rabies in striped skunks in Eastern Montana (1964-1973), skunks alone are responsible reservoirs for the disease. These reservoirs may have stemmed from endemic skunk rabies areas of Saskatchewan and North and South Dakota. Records available from the Animal Health Division, Department of Livestock, indicate the range and distribution of rabies since 1964 are widely scattered in time and space. The introduction of skunk rabies into Montana parallels the frequency or migration of skunk rabies in Saskatchewan and the Dakotas. "Spillover" from these areas still seems to prevail in the scope of skunk rabies in Montana. No skunk rabies cases have been diagnosed in the western half of Montana.

Rabies in striped skunk has been diagnosed in each month of the year since 1964; however, the majority of cases have occurred during March. April. May. and June (see Table 1).

Sylvatic rabies diagnosed in striped skunks was recorded at an all time high during the first five months of 1973 in Montana. Nineteen rabid skunks were diagnosed during this period. This increase in rabid skunk findings over any other year may be due to more people participating in outdoor recreation, cyclic patterns of the disease, reduced skunk control because of the federal ban on toxicants, or increased number of skunks submitted as a result of trapping instead of previous control procedures.

A program of trapping and shooting was initiated during March and April of 1973 by the Montana Department of Livestock to suppress skunk populations in the immediate vicinity of confirmed rabid skunk cases. These control measures proved ineffective and costly. In May of 1973 the U. S. Environmental Protection Agency was contacted and a formal request made for the use of strychnine eggs as an emergency control method. An Environmental Impact Statement was also prepared. On June 6, 1973 approval was received to carry out a rabies control program using strychnine eggs.

\section{PURPOSE AND OBJECTIVES}

The purpose of this rabid skunk control program was to prevent exposure of domestic animals and man to rabid skunks, thereby preventing domestic animal and human death from rabies and the need for post exposure human antirabies treatment. 
Table 1. Summary of positive rabid skunk cases occurring in Montana from 1964 to 1973*

\begin{tabular}{|c|c|c|c|c|c|c|c|c|c|c|c|c|c|}
\hline Year & Jan. & Feb. & Mar. & Apr. & May & June & July & Aug. & Sept. & $0 \mathrm{ct}$. & Nov. & Dec. & Total \\
\hline 1964 & & & & 2 & & & 1 & & & & 1 & 1 & 5 \\
\hline 1965 & 2 & & & & & & & & & & & 1 & 3 \\
\hline 1966 & 1 & 3 & 2 & 7 & 1 & & & & & & & & 14 \\
\hline 1967 & & & & & 1 & 1 & & 1 & & & & & 3 \\
\hline 1968 & & & & & 2 & 4 & & & 1 & & & 1 & 8 \\
\hline 1969 & 1 & 1 & 1 & & & 1 & & & & & & & 4 \\
\hline 1970 & & & & & & & & & & & & 1 & 1 \\
\hline 1971 & & & & & & 1 & & & & & & & 1 \\
\hline 1972 & & & & & & 1 & 2 & 2 & & & & & 5 \\
\hline 1973 & & & 2 & 11 & 8 & 4 & 2 & 1 & 2 & 2 & 4 & 2 & 38 \\
\hline TOTAL & 4 & 4 & 5 & 20 & 12 & 12 & 5 & 4 & 3 & 2 & 5 & 6 & 82 \\
\hline
\end{tabular}

* Information collected from the Montana Department of Livestock Diagnostic Laboratory -Bozeman, Montana.

The objectives of the skunk control program were: 1) to reduce the striped skunk populations within a three mile radius where rabid skunks were diagnosed, 2) to collect data on the effectiveness of strychnine eggs on reducing striped skunk populations, 3) to study the effects of strychnine eggs on non-target species.

METHODS

Strychnine eggs were used to reduce skunk populations in Northeast Montana. One-eighth ounce of strychnine alkaloid powder was dissolved in $90 \mathrm{cc}$. of water and $10 \mathrm{cc}$. of concentrated glacial acetic acid. As a precaution, the solution was colored green by adding three through five drops of food coloring. One cc. of strychnine solution was administered to each egg with a hypodermic syringe. A maximum of 500 strychnine eggs could be placed in designated skunk habitat within a three mile radius where rabid skunks were diagnosed. A maximum of two strychnine eggs per setting were placed in the following skunk habitat: 1) road culverts, 2) non-occupied buildings, 3) skunk dens, 4) holes, 5) garbage dumps, 6) junk piles, and 7) rock piles. Eggs remaining after a 30 day period from date of placement were collected and destroyed.

Strychnine eggs were placed only on those lands where Premise Entry Agreements were signed by the landowner, leasee, or administrator. Warning signs were posted at entries to all premises and other visible positions near locations of placed, treated eggs. Additional warning signs were placed on stakes at each egg. State trappers licensed as Pesticide Applicators carried out control activities.

Scent post surveys were used in conjunction with the emergency skunk control program to measure relative abundance of wild ife species and to note any fluctuations in skunks and other animal populations after toxicants were utilized.

To investigate the disappearance of strychnine eggs in rabies control areas, track surveys were conducted. Finely sifted dirt was first used and later regular flour. Nontoxic eggs were placed in road culverts with dirt or flour at both entrances. For a period of ten days a total of 90 track stations were checked daily. Animal tracks were 
recorded, as well as any eggs that were eaten or missing. Old tracks were covered each day with fresh dirt or flour. Eggs were replaced if eaten or missing.

\section{RESULTS AND DISCUSSION}

Strychnine eggs were placed with few exceptions in culverts, junk piles or dumps, rock piles, ground dens and holes, and under non-occupied buildings. These areas represented prime skunk habitat and, at the same time, provided locations where eggs were not in view of predatory birds, humans, and domestic animals; however, it was known that other non-target species frequented these areas. Table 2 summarizes the numbers and species taken during the control program. Striped skunks were the predominant species taken with strychnine eggs. Various species of small rodents (Peromyscus, Mus, Zapus, Citellus spp.) were taken most frequently of all non-target species, followed by red foxes(Vulpes fulva) and badgers (Taxidea taxus).

Table 2. Summary of strychnine egg program in Northeastern Montana Counties of Sheridan, Blaine, and Daniels.*

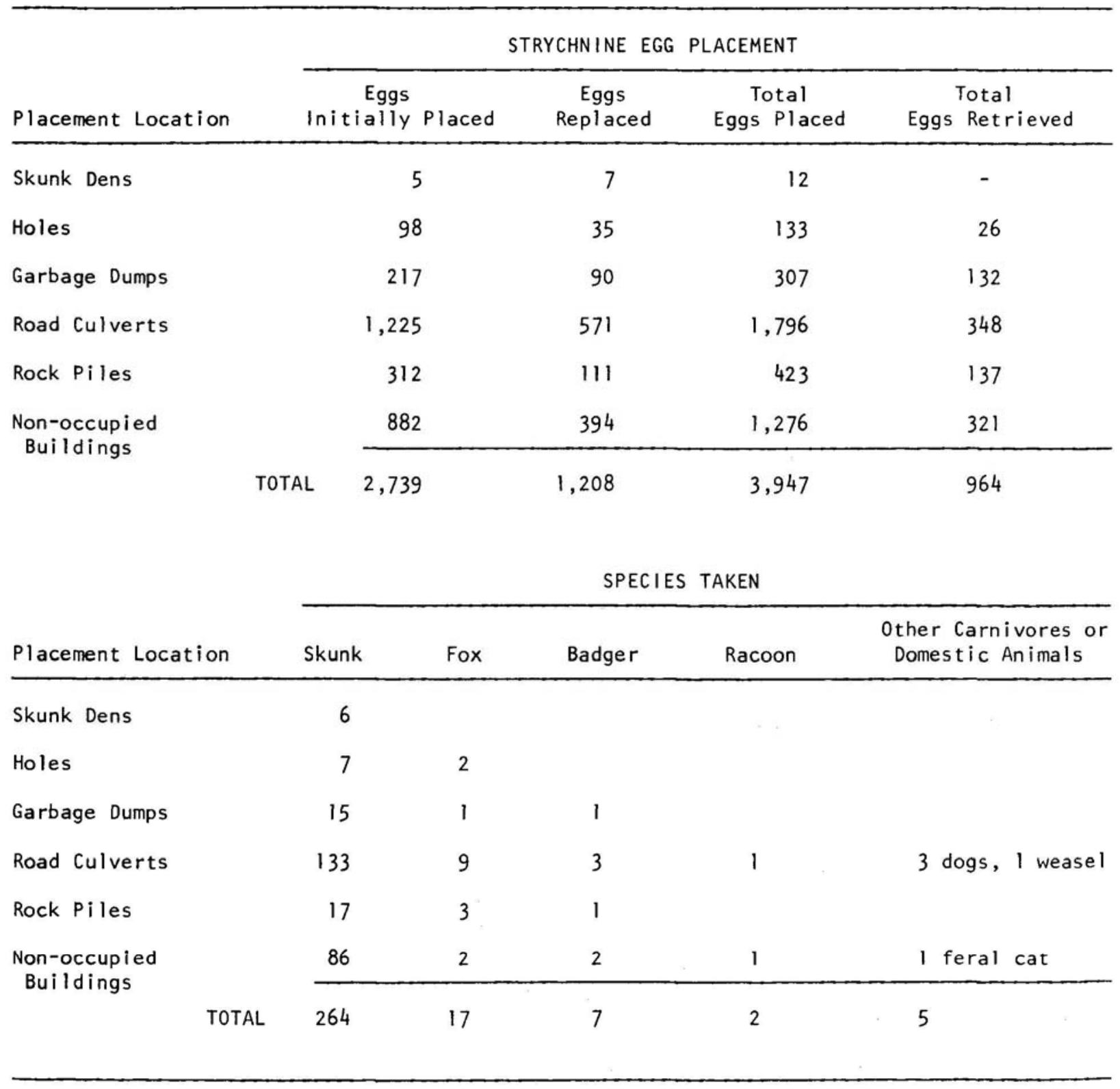

* Control program initiated June 9, 1973 and terminated October 31, 1973. 
Skunks were taken most often in road culverts and non-occupied buildings. Few were taken in rock piles, junk piles, or ground dens. Foxes and badgers appeared to frequent rock piles and road culverts more than any other egg location areas. Rodents (mice, ground squirrels, porcupines (Erethizon dorsatum) were extremely numerous in all locations. Few domestic animals were encountered. Raccoons (Procyon lotor) were abundant, but only two were taken with strychnine eggs.

Road culverts and non-occupied buildings located within a quarter mile of occupied dwellings were bypassed, unless the landowner requested eggs in those areas.

Skunks taken with strychnine eggs were found within a range of up to 90 feet from the eggs. In most cases musk was emitted. It is believed that with a few exceptions, all skunks eating toxicant eggs were found.

The seventeen foxes taken were readily visible in summer-fallow fields, low grass fields, and near roads. The eggs that took foxes were often missing. Similarly, fox and raccoon tracks were visible near the disappearance of a considerable number of eggs. Additional animals were possibly concealed by tall wheat, grasses and brush, however, landowners and people frequenting the control areas reported few animals taken not reported by state personnel.

It is known that raccoons were breaking strychnine eggs. Preliminary observations indicated that raccoons were breaking the eggs, but not consuming the contents. Evidence was found that raccoons may have regurgitated the egg contents soon after eating it.

Rodents destroyed and consumed a significant number of strychnine eggs; however, few rodents were taken. Of those found, most rodents had licked around the injection hole in the egg. Insects quickly attacked the eggs once rodents had created sizeable holes in the shells. On several occasions, porcupines were observed in culverts where eggs were placed. In only one instance was a porcupine taken with a strychnine egg. All known porcupines were still present when eggs were retrieved. Three domestic dogs (Canis familiaris) were suspected of eating strychnine eggs. None of the dogs were confirmed to have eaten an egg, but indications are that they did.

The location of strychnine eggs appears to be important in carrying out a successful toxicant program. Eggs placed in road culverts and under non-occupied buildings took the majority of skunks. Principally non-target species were taken at rock piles during initial control efforts. For this reason, rock piles were excluded as areas of control. Ground dens and junk piles were frequented by considerable numbers of rodent species.

Table 3 shows a population breakdown of animal species taken during the control program. A significantly larger proportion of adult skunks were taken by strychnine eggs. This could possibly reflect the time of year in which control activities were carried out, as well as the inability of juvenile skunks to break the eggs. Removal of adult skunks during June and July probably resulted in the loss of many litters of juvenile skunks. This could have resulted in a much larger effect on the skunk populations than Table 3 shows. This theory is supported by a few reports of orphaned skunk litters sighted by private landowners, as well as state trappers.

An insignificant number of red fox, badgers, raccoons, or domestic animals were taken as a result of strychnine eggs. It was evident from tracks and actual sightings that high populations of these species occurred in the control areas. Considerable trapping pressure occurred during the past fur season in many of the rabies control areas. Private trappers reported a large fur catch of red fox, coyotes, and badger.

Scent post surveys (Table 4) conducted before and after toxicant egg use, showed some fluctuations in species. The striped skunk appeared to have decreased in number at the termination of the control program. All other species surveyed in control areas increased or remained relatively stable. It would be expected that scent post visits should increase in August surveys due to recruitment of young animals and increased animal activity.

Track surveys revealed some information as to the disappearance of numerous strychnine eggs. Table 5 shows that the principle species removing eggs from culverts were red foxes and raccoons. Raccoons and badgers often consumed non-toxic eggs in close proximity to the egg station. However, in all cases where red fox removed an egg, the egg was never located. Heavy rains also accounted for many missing eggs. Eggs were found several 
hundred feet into fields and many times entangled under vegetation. Other probable causes for egg loss include wind, insects, porcupines, and birds.

Table 3. Population structure of carnivore species taken during the toxicant egg program in Northeast Montana.

\begin{tabular}{|c|c|c|c|c|c|c|c|}
\hline \multirow[b]{2}{*}{ Species } & \multicolumn{3}{|c|}{ Age } & \multicolumn{3}{|c|}{ Sex } & \multirow[b]{2}{*}{ Total } \\
\hline & Adult & Juvenile & Unknown & Male & Female & Unknown & \\
\hline Striped Skunk & 197 & 40 & 27 & 54 & 49 & 161 & 264 \\
\hline Red Fox & 8 & 6 & 3 & 3 & 2 & 12 & 17 \\
\hline Badgers & 3 & 3 & 1 & 5 & 1 & 1 & 7 \\
\hline Raccoon & 2 & & & & & 2 & 2 \\
\hline Weasel & 1 & & & & & 1 & 1 \\
\hline Feral Cat & 1 & & & & & 1 & 1 \\
\hline Domestic Dog & & 1 & 2 & 1 & & 2 & 3 \\
\hline
\end{tabular}

Table 4. Predator scent post survey in Sheridan County, Montana.*

\begin{tabular}{|c|c|c|c|c|c|c|c|c|c|c|}
\hline \multirow[b]{2}{*}{ Species } & \multicolumn{4}{|c|}{$\begin{array}{l}\text { June } 9-10,1973 \\
\text { Line Number }\end{array}$} & \multicolumn{6}{|c|}{$\begin{array}{c}\text { August } 29-30,1973 \\
\text { Line Number }\end{array}$} \\
\hline & 1 & 2 & 3 & 4 & Total & 1 & 2 & 3 & 4 & Total \\
\hline Skunk & 6 & 7 & 8 & 15 & 36 & - & 1 & 1 & 3 & 5 \\
\hline Fox & 10 & 4 & 4 & 13 & 31 & 11 & 10 & 13 & 13 & 47 \\
\hline Feral Cats & 1 & 3 & - & 2 & 6 & 5 & 6 & 5 & 2 & 18 \\
\hline Raccoon & 4 & 2 & 1 & 6 & 13 & 1 & 3 & 6 & 3 & 13 \\
\hline Badger & 1 & - & - & - & 1 & 1 & - & - & - & 1 \\
\hline $\begin{array}{l}\text { Other } \\
\text { Carnivores }\end{array}$ & & & & & & 1 & eas & & & 1 \\
\hline
\end{tabular}

* This data represents only the number of species visitations as recorded by the investigators. 
Table 5. Summary of animal species removing or consuming non-toxic eggs from dirt and flour stations in road culverts during track surveys in Northeastern Montana.*

\begin{tabular}{|c|c|c|c|c|}
\hline Species & Number of & Eggs Missing & Number of Eggs Eaten at Station & Total Eggs \\
\hline Raccoon & & 18 & 25 & 43 \\
\hline Red Fox & & 17 & - & 17 \\
\hline Badger & & - & 4 & 4 \\
\hline \multirow[t]{2}{*}{ Unknown** } & & 13 & 4 & 17 \\
\hline & TOTAL & 48 & 33 & 81 \\
\hline
\end{tabular}

* Table represents combined data from three track suryey areas.

** Heavy rain assumed to be the cause for egg disappearance.

LITERATURE CITED

ADVISORY COMMITTEE ON PREDATOR CONTROL. 1972. Predator control-1971. Stanley Cain, Chairman. Institute for Environmental Quality. Univ. of Michigan, Ann Arbor, Michigan.

ALSAGER, DALE. 1971. Rabies vector control - skunk depopulation, buffer zone. Animal Pest Control, Dept. of Ag., Alberta.

BUREAU OF SPORT FISHERIES AND WILDLIFE. 1967. Controlling skunks. Division of Wildife Services, Washington, D. C. 20240.

LEWIS, JAMES. 1971. Factors influencing reports of rabid animals in oklahoma. Journal of Wildife Diseases. Vol. 8, July 1972 .

LEOPOLD, A. STARKER. 1964. Predator and rodent control in the United States. Trans. N. Am. Wild life Conf. 29:27-49.

MONTANA DEPARTMENT OF AGRICULTURE. 1973. Interim report on rodent and rabid skunk control.

PARKER, R. L. and WILSNACK, R. E. 1966. Pathogenesis of skunk rabies virus: quantitation in skunks and foxes. Am. Journal of Vet. Research. 27(116).

SIKES, R. K. 1971. Report of the committee on rabies. Rabies Control Unit. CDC. Atlanta, Georgia.

STORM and VERTS. 1966. Movements of a striped skunk infected with rabies. Journal of Mammalogy, 47(4):705-708, December.

VAN DER VEER. 1971. Report on rabies hysteria. Defenders of Wildlife News - Su., July.

VERTS, B. J. 1965. The biology of the striped skunk, Mephitis mephitis (Schreber), and its role in the epizootiology of rabies in northwestern Illinois. Southern Illinois Univ.

- and STORM. 1966. A local study of prevalence of rabies among foxes and striped skunks. Journal of Wildlife Management. 30 (2):419-421, April.

WINKLER, W. G. 1971. Rabies in the U.S. 1951-1970. Journal of Infection Diseases. $125(6)$, June, 1972 .

WORLD HEALTH ORGANIZATION. 1966. WHO expert committee on rabies. Fifth Report. WHO, Geneva.

. 1966. WHO expert committee on rabies. Technical Report No. 321. Geneva. 